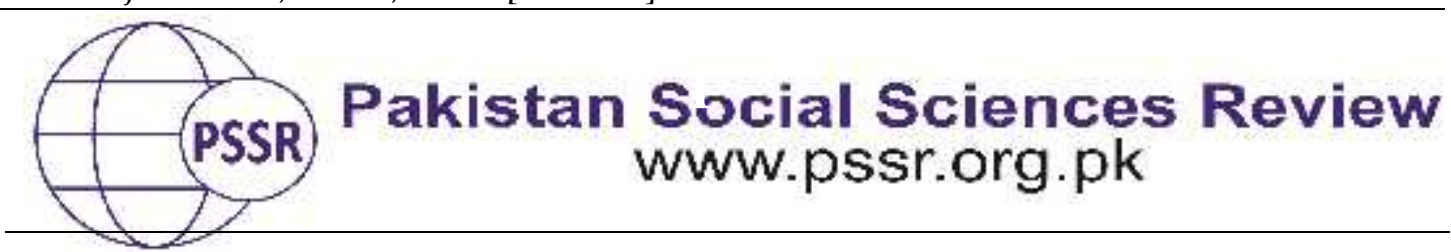

RESEARCH PAPER

\title{
Pakistan's General Elections 2013: Analysis of Time Magazine and The Economist
}

\author{
Dr. Muhammad Rashid Khan ${ }^{1}$ Asmat Ullah ${ }^{2}$ Muhammad Karim Ahmed ${ }^{3}$
}

1. Assistant Professor, Institute of Communication Studies, University of the Punjab, Lahore, Punjab, Pakistan

2. Independent Researcher and Development Expert, Islamabad, Pakistan

3. M Phil, Centre for Communication and Media Studies, University of Gujrat, Gujrat, Punjab, Pakistan

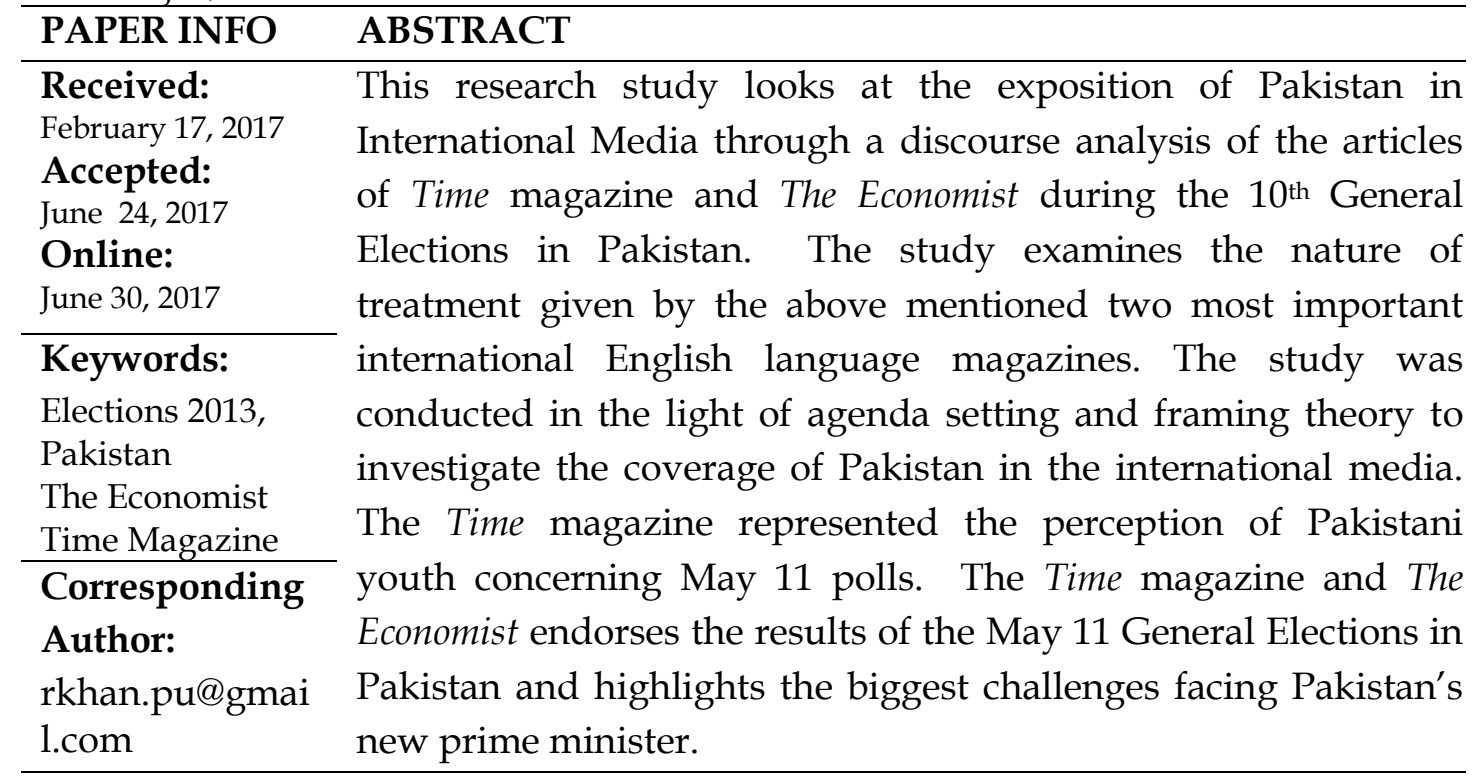

Introduction

The role of media is to shape opinions and present an objective account about the events and issues. Media is also believed and expected to portray a fair picture on issues occurred both at local and international levels. In order to examine the portrayal of Pakistan in international media two international magazines namely the Time magazine and The Economist have been selected for the discourse analysis. These magazines constituted the mainstream print media. This study examines the nature of treatment given by the above mentioned two most important international English language magazines on the specific issues of Pakistan related to General Elections of May 2013. It thrashes out the similarities and differences between the contents of the articles of these magazines. The rationality behind the selection of these news magazines is that both the magazines are international magazines having vast circulation and popularity. These 
magazines provide in-depth reporting and analysis of current events around the world.

\section{TIME Magazine}

Time (styled within the magazine as TIME) is an American weekly published in New York City. It was founded in 1923 and for decades was dominated by Henry Luce, who built a highly profitable stable of magazine. Time has the world's largest circulation for a weekly news magazine, and as of 2015, its circulation was 3,036,602. Nancy Gibbs has been the managing editor since October 2013(time.com).

\section{The Economist}

Established in 1843 to campaign on one of the great political issues of the day, The Economist remains true to the principles of its founder. James Wilson, a hat maker from the small Scottish town of Hawick, believed in free trade, internationalism and minimum interference by government, especially in the affairs of the market. Though the protectionist Corn Laws which inspired Wilson to start The Economist were repealed in 1846, the newspaper has lived on, never abandoning its commitment to the classical 19th-century Liberal ideas of itsfounder.

\section{Literature Review}

This portion reviews studies on the factors that affect the frames in news media, coverage of foreign nations having an agenda setting influence or not, U.S image in the Pakistani elite newspapers, and coverage of South Asia in leading U.S newspapers.

De Vreese (2012) examines the frames, frames building and effects of frames. The researcher reviews the studies mentioned in the special issue of the American Behavioral Scientist. The author analyzes the contents and specifically the concept of framing in political communication research. The researcher in this study suggests for the conceptual clarity regarding framing and also makes certain recommendations for framing research which are related to the types of frames that framing researcher must look at, these are advancement in the framing research design and the dynamics of framing effects. Hanggli (2012) tries to find out the factors that affect the frames in news media. The researcher collects data from content analysis technique and finds that for the presence of frame, power is important.

Shen and Edwards (2007) explain that the recent researches in the field of framing indicate that the impact of framing varies from person to person. The study examines the way in which individuals' personal values play a role to interact with news frames when they affect their opinion and cognitions. Findings 
of the study suggest that the news frame and values of individuals both have a significant impact on the thoughts, opinion and attitude of individuals.

Wanta, Golan and Lee (2003) examine whether the coverage of foreign nations have an agenda setting influence or not. The findings suggest that the more coverage to a nation in the newscasts is given, the more likely the research respondents think that the nation is vitally important to U.S. Similarly, the more negative coverage given to the nation, the more likely the respondents think negatively about the nation.

Salim (2000) evaluates the U.S image in The Pakistan Times and Dawn. The findings of the study maintain that where there is mutual agreement between Pakistan and U.S on any issue the U.S image is framed positively. Scheufele (1999) describes that most of the research related to framing are mainly considered or characterized as empirically and theoretically indefinite or vague. According to the researcher the main reason behind this is the lack of a theoretical model which is commonly shared by the researcher for the research related to framing. The researcher tries to organize the fragmented approaches related to framing and combined them into a comprehensive model. The findings suggest that the four key processes such as frame building, frame setting, process of framing at individual level and a loop of feedback from audience to journalists must be addressed in future research related to framing.

Poornanda (1998) in an article on "Coverage of South Asia in two leading U.S newspapers" concluded that the U.S media, The Los Angeles Times and The Washington Post gave very marginal coverage to the third world, specifically South Asian countries during a time period from 1992-1996.The both leading newspapers ofU.S focused on the negative stories more than the positive one in the coverage given to SouthAsia.

\section{Theoretical Framework}

The researcher intends to study the coverage of Pakistan in international media through an analysis of the Newsweek, and Time magazines during 2013 by applying the theoreticalperspectives of AgendaSettingand Framing.

\section{1 - Agenda Setting Theory}

According to Tankard and Severin (1992:70), "Agenda setting is the idea that the news media by the display of news, come to determine the issues the public think about and talk about. Agenda setting describes a very powerful influence of the media- the ability to tell us what issues are important. Agendasetting is the creation of public awareness and concern of salient issues by the news media. Agenda-setting theory seems quite appropriate to help us understand the pervasive role of the media (for example on political communicationsystems)." 


\section{2 - Media Framing}

During the agenda setting media often have a preference to encourage or refuse some news. Basic factor in agenda setting is the process of framing the stories. It is an analyzing method that how news media defined the issues of public interest. It develops the public opinion about any issue either positively or negatively.

\section{Research Design}

The study is conducted in the light of agenda setting and framing theory to investigate the coverage of Pakistan and its portrayal in the Time magazine and The Economist by using discourse analysis technique. The data of the study include all articles using the word Pakistan General Elections during 2013.

\section{Population}

Entire population of article published in the Time magazine and The Economist during the year2013 are the population of the study, whereas a sample of articles which contains the word "Pakistan General Elections 2013" are drawn from the population for the purpose of study. So for the selection of article, convenience sampling technique is employed. Researcher read whole material many times for the accuracy of findings of research.

\section{Discourse Analysis}

Anticipating the apprehensions of terrorism on May 11, 2013 General Elections in Pakistan, the Time magazine in its column "Briefing" under the title of "A Giant Leap for Pakistani Democracy" by Andrew Katz and Dan Macsai (2013, April 01) reads: "Five years ago, few would have predicted that Pakistan's new civilian led democratic government could last. It would be, after all, an unprecedented feat in the nation's 65 year history; every previous elected government was brought down by a military coup or subtler means. And yet it's March 2013, and the government has survived its full five year term.

But there's much more work to do. Although the government, led by President Asif Ali Zardari, has made notable advances allowing dissenting opinions and passing important constitutional amendments the country faces persistent threats; flood damage, terrorism, power struggles, a sluggish economy, insurgencies, tensions with India and more.That's why many Pakistanis are eagerly anticipating elections on May 11. Fears loomthat the campaign may turn bloody, as the previous one did when Prime Minister Benazir Bhutto, Zardari's wife, was assassinated in late 2007. Still, this will be Pakistan's first opportunity to replace one government with another at the ballot box. That's worth celebrating." 
In another new feature the Time magazine tries to represent the perception of Pakistani youth concerning May 11 polls. Citing the statistics of a survey, the writer Aryn Baker (2013, April 22) in her "viewpoint" captioned "For young Pakistanis, Democracy's a Drag" with a catch line "Despite years of military rule, a nation's youth can't get excited about civilian government. Here's why" reads:"If a country's future is determined by its youth, Pakistan's is grim. In a recent survey of Pakistanis aged 18 to 29 (a demographic making up nearly half the population), $94 \%$ said the nation was going in the wrong direction. More alarmingly, few had faith in democracy's ability to set things right ironic, considering that polls on May 11 will see, for the first time in the country's 65 year history, a transfer of power from one democratically elected civilian government to another. According to British Council's Next Generation Report, only 23\% of the 5271 youths interviewed believe democracy has been good for Pakistan, a stunning condemnation for a country that broke free of nine years of military dictatorship in 2008. But perhaps the antipathy shouldn't be surprising. The Pakistan People's Party-led government that just stepped down may have been the first to complete a full term, but its tenure was marked by inflation, corruption, unemployment and debilitating energy crisis.

If democracy can't save Pakistan, what will? "Thirty two percent of youths said military rule would be more effective, and 38\% thought Sharia, the style of Islamic law used in Saudi Arabia (and brutally imposed by the Taliban in Afghanistan in the 1990) was the solution. Only 29\% thought democracy was the way forward."

On this feedback, the news feature sparks debate "At the root of this is a yearning for effective government something that democracy has so far failed to deliver. Military rule and Taliban style justice promise quick fixes, but neither is a variable form of government in the long term. It's difficult to scale up to national level the 7thand 8thcentury eye for an eye laws of Sharia however useful may be at settling village disputes. The effectiveness of military rule is illusory. Any general can appear decisive when there is no opposition. But juntas inevitably focus on security issues, to the detriment of growth and social development."

The report sets the agenda "The ballot box is the only political tool that offers Pakistan a long term fighting chance. Unfortunately, many Pakistanis don't see it that way. The only military rule most young Pakistanis have known was that of General later President, Pervez Musharraf, who overthrew Prime Minister Nawaz Sharif in late 1999. Under Sharif, Pakistan was bedeviled by corruption, inflation and crime. But during Musharraf's time, it was made prosperous not by his efforts but by the caprice of history. Not long after Musharraf took power the September 11 attacks on the US fundamentally changed the relationship between Washington and Islamabad. Long standing sanctions related to Pakistan's development of nuclear weapons, as well as Musharraf's coup, were dropped, and Pakistan became the beneficiary of significant military and financial support. 
Massive development projects changed the face of its cities, and the Pakistani rupee hovered around 55 to the dollar (it now trades at 98). No wonder young Pakistanis are such fans of military rule."

The writer extends its progressive ideas "Similarly, they admire Sharia because they see it as an upright alternative to the incompetence and malfeasance of secular administrations. In the non-Muslim world, Sharia has a bad name. The very word suggests Taliban zealots amputating the hands of petty thieves and stoning young adulterers. In Pakistan, however, religious myth making propagated in the country's madrassas and mosques equates Sharia with speedy and visible justice. It is a beguiling alternative in a country where the native in a country where the backlog in the courts means that even minor cases can take anywhere from 10 to 18 years to be resolved.

In a situation, if young Pakistanis are not giving democracy a chance, "it's because they haven't seen it do what democracy does best; holding those in power accountable. An incompetent Pakistani government has never been punished at the polls. The military has always stepped in first. But if voters are allowed to effect a change themselves, democracy's standing willrise."

The feature article concludes "It is unlikely that the next parliament will be any more effective than the last, since there are few fresh faces running. But when there are new polls five years from now, the lesson of accountability will begin to sink in, both for voters and politicians. Pakistan's youth may be skeptical, but $61 \%$ said they were likely to vote next month nonetheless, and $77 \%$ thought their generation would make Pakistan a better country. If they begin voting out their politicians, then they will."

In yet another news analysis the Time magazine highlights "Three biggest challenging facing Pakistan's new prime minister." The "Briefing" (2013, April 29) reads: "By May 11, Pakistanis will have elected a new government helmed either by Imran Khan (the cricket returned anticorruption activist) or Nawaz Sharif (The pro-business conservative). Here's what the winner is up against.

Keeping the lights on: "Pakistan's electricity service has been spotty for years, causing 18 - hour blackouts in some cities. Government funds must be reallocated to generate more power more efficiently." Placating militants: "The new leadership is expected to broker a peace deal with the Pakistani Taliban to avoid attacks, but such efforts haven't worked in the past." Ousting ones: "Pakistan, which allows US drones to attack from its airspace, wants to end its cooperation with the CIA. But it still needs US aid to sustain its economy."

Time magazine endorses the results of the May 11 General Elections in Pakistan. A news "Briefing" titled "A political tiger returns from the wild in Pakistan" (2013, May20) reads: "As the results of Pakistan's election became apparent in the early hours of May 12, cheering supporters of Nawaz Sharif spilled 
out into the streets of Lahore. Sharif's party had beaten expectations and was cursing toward a convincing victory that gave it control of the national parliament. Young men whizzed by on motorbikes, fluttering party flags attached at the back. "Look, look who has come! The tiger has come, the tiger has come!" they chanted, referring to Sharif's election symbol.

The tiger has been there before, though. In 1999, then Prime Minister Sharif was overthrown in a military coup by General Pervez Musharraf. He was tossed jail and later dispatched into exile for seven years. In his absence, some claimed that Sharif's party and his political career were finished. Now, in an astonishing the turn, Sharif is set to become Pakistan's Prime Minister for the third time, while Musharraf is under arrest and will possibly face trial for alleged crimes involving abuse of power.

Sharif, a pro-business politico with a religiously conservative bent, has much to do. He'll have to resolve Pakistan's crippling electricity shortages and boost its sluggish economy. He must confront the Pakistani Taliban despite a mixed previous record of dealing with domestic militants. And he must strike a balance between managing relations with Washington and assuaging with US sentiment at home.

It was a disappointing night for cricket legend Imran Khan, the dashing candidate for 'change' who surged into Election Day on a wave of support from youth and the urban middle class. His party failed to secure a breakthrough, finishing second and winningabout 35 out of 242 seats in Parliament. Although Khan alleges widespread vote rigging, the former star athlete was no match for the re-born tiger."

"A peaceful handover of power and the emergence of a new political player? It's a start," comments Time magazine's Aryn Baker (2013, May 27) in a news feature captioned "Hope and Change, Pakistani Style. The analysis reads "No argument: Pakistan's May 11 general election was a singular milestone. For the first time in a 66 year history riddled with coups, a civilian government that completed its full five year term was replaced, by voting Pakistanis, with another civilian administration. Military brass continues to glint in the shadows, but the army kept to its barracks.

The news isn't all good. Though the results confirm the victory of Nawaz Sharif and his Pakistan Muslim League (Nawaz) PMLN, party vaulting him to the prime minister ship for the third time - they also reveal how little has changed. In a country whose default direction for the past decade has been downhill, that's not only disappointing but potentially dangerous. The hope on the horizon lies in the person of onetime political nobody Imran Khan. The 60 year old former cricket star swore he would sweep into the Prime Minister's office, buoyed by youthful voters eager for change. That was never going to happen. The Pakistani political system 
leaves little room for newcomers but Khan's fledgling Pakistan Tehreek-e-Insaf (Pakistan's Movement for Justice) has adroitly moved into what room there is."

\section{The Economist}

The Economist also provides guidelines to the newly elected prime minister of Pakistan. Its news feature titled "Pakistan's election: Hope over experience Nawaz Sharif's third turn as prime minister could be his luckiest (2013, May 18) reads:"Mr. Sharif might dare to think of root-and-branch ways to modernize the economy, as he did in his first, liberalizing rule at the start of the 1990s. Then, freeing Pakistan's economy inspired India's Mr. Singh (finance minister at the time) to do the same next door. Privatizing several bloated state-owned firms, or at least running them better, could kick-start the economy.

Indeed, revamping steel and power companies and the national airline could, some who know him say be on Mr. Sharif's mind. If so, he needs to move fast. A new deal with the IMF is needed in the coming months, as official reserves dwindle and debt repayments loom. Get the economy going again, Mr. Sharif says, and all of Pakistan's other problems can be fixed more easily."

\section{Conclusion}

In order to examine the coverage of Pakistan in international media two international news magazines namely the Time magazine and The Economist were selected for the discourse analysis with regard to the General Elections of May 2013. The Time magazine represented the perception of Pakistani youth concerning May 11 polls. It reads that few had faith in democracy's ability to set things right ironic, considering that polls on May 11 will see, for the first time in the country's 65 year history, a transfer of power from one democratically elected civilian government to another. The Time magazine considers the ballot box is the only political tool that offers Pakistan a long term fighting chance.

It is unlikely that the next parliament will be any more effective than the last, since there are few fresh faces running. The Time magazine highlights the biggest challenges facing Pakistan's new prime minister. Pakistan's electricity service has been spotty for years, causing 18-hour blackouts in some cities. Government funds must be reallocated to generate more power more efficiently. The new leadership is expected to broker a peace deal with the Pakistani Taliban to avoid attacks.

Time magazine endorses the results of the May 11 General Elections in Pakistan. Sharif is set to become Pakistan's Prime Minister for the third time. He will have to resolve Pakistan's crippling electricity shortages and boost its sluggish economy. He must confront the Pakistani Taliban despite a mixed previous record of dealing with domestic militants. And he must strike a balance between managing relations with Washington and assuaging with US sentiment at home. 
On the peaceful handover of power Time magazine says Pakistan's May 11 general election was a singular milestone.

The Economist also provides guidelines to the newly elected prime minister of Pakistan. Mr. Sharif might dare to think of root-and-branch ways to modernize the economy, as he did in his first, liberalizing rule at the start of the 1990s. Then, freeing Pakistan's economy inspired India's Mr. Singh (finance minister at the time) to do the same next door. Privatizing several bloated state-owned firms, or at least running them better, could kick-start the economy. Indeed, revamping steel and power companies and the national airline could. A new deal with the IMF is needed in the coming months, as official reserves dwindle and debt repayments loom. Get the economy going again and all of Pakistan's other problems can be fixed more easily, The Economist discourses. 


\section{References}

Baker, Aryn. (2013, April 22). For Young Pakistanis, Democracy's a Drag: Despite years of military rule, a nation's youth can't get excited about civilian government. Here's why. Time.Hong Kong: TimeInc.

Baker, Aryn. (2013, May 27). Hope and Change, Pakistani Style: A peaceful handover of power and the emergence of a new political player? It's a start. Time.Hong Kong: TimeInc.

Briefing. (2013, April 29). Three biggest challenging facing Pakistan's new prime minister. Time.Hong Kong: Time Inc.

Briefing. (2013, May 20). A Political Tiger Returns From the Wild in Pakistan. Time. Hong Kong: Time Inc.

De Vreese., \& Claes, H. (2012). News Avenues for Framing Research. American Behavioral Scientist.56(3). Doi:10.1177.0002764211426331.

Hanggli, R. (2012. Key Factors in Frame Building: How Strategic Political Actors Shape News Media coverage. American behavioral Scientist.56(3).Doi: $10.1177 / 0002764211426327$.

Katz, Andrew \& Macsai, Dan. (2013, April 01). Briefing: A Giant Leap for Pakistani Democracy. Time. Hong Kong: TimeInc.

Poornananda, D.S (1998).Coverage of South Asia in two leading U.S newspapers. Media Asia, 23(3),p.161-166

Salim.(2000). U.S image in The Pakistan Times and Dawn.In Khan, M. A. and Zaheen, B. (Autumn 2014).US Mass Media and Image of Pakistan: An Analysis ofNewsweek and the Economist after Salala Incident. Journal of Social Sciences and Humanities: Volume 22, Number2.

Scheufele, D. (1999). Framing as a Theory of Media Effects. Journal of Communication,49,103-122.doi:10.1111.j.1460-2466.1999. tb02784.X.

Shen \& Edwards.(2007). News frame and values of individuals. In Khan, M. A. and Zaheen, B. (Autumn 2014).US Mass Media and Image of Pakistan: An Analysis of Newsweek and the Economist after Salala Incident. Journal of Social Sciences and Humanities: Volume 22, Number2.

Wanta, Golan \&Lee. (2003). Whether the coverage of foreign nations have an agenda setting influence or not? In Khan, M. A. and Zaheen, B. (Autumn2014).US Mass Media and Image of Pakistan: An Analysis of Newsweek and the Economist after Salala Incident. Journal of Social Sciences and Humanities: Volume 22, Number2. 